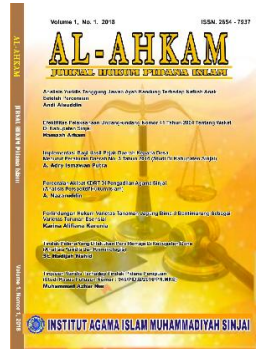

\title{
PELAKSANAAN HUKUM KEWARISAN ISLAM PADA MASYARAKAT ADAT KARAMPUANG DI KECAMATAN BULUPODDO KABUPATEN SINJAI
}

\author{
Eril $^{1}$, St. Hadijah Wahid ${ }^{2}$ \\ ${ }^{I}$ IAI Muhammadiyah, Jl. Sultan Hasanuddin No. 20, Sinjai \\ ${ }^{2}$ IAI Muhammadiyah, Jl. Sultan Hasanuddin No. 20, Sinjai \\ E-mail: erilcudding@gmail.com,Tlp:085398821402
}

\begin{abstract}
Abstrak
Penelitian ini bertujuan untuk mengetahui praktik pembagian harta kewarisan adat, dan pelaksanaa hukum kewarisan Islam pada masyarakat adat Karampuang, di Kecamatan Bulupoddo Kabupaten Sinjai. Jenis penelitian ini deskriftif kualitatif (field research) dan pendekatan penelitian yang digunakan; normatif (syar'i), pendekatan yuridis formal, pendekatan sosiologis, pendekatan normatif, pendekatan fenomenologis. Adapun sumber data penelitian ini adalah para tokoh adat, ahli waris, tokoh agama dan tokoh masyarakat, selanjutnya metode pengumpulan data yang digunakan adalah observasi, wawancara, dokumentasi dan penulusuran referensi. Lalu, teknik pengolahan dan analisis data dilakukuan melalui tiga tahap, yaitu; reduksi data, penyajian data dan penarikan kesimpulan. Berdasarkan penelitian yang penyusun lakukan, bahwa kewarisan pada masyarakat adat Karampuang menganut Sistem keturunan dengan memberikan secara otomatis pengelolaan harta warisan jatuh kepada anak laki-laki tertua atau anak perempuan tertua yang diberikan mandat kepada pewaris dalam mengatur harta warisan setelah pewaris wafat, hanya saja pada harta tertentu seperti sawah, kebun, uang dan emas tetap diadakan pembagian kepada ahli waris lainnya. Hal ini bertujuan untuk memberikan bekal bagi para ahli waris tersebut, hanya saja bagian harta warisan untuk anak laki-laki tertua atau anak perempuan tertua lebih banyak. sistem dan praktik pembagian harta warisan pada masyarakat adat Karampuang tidak sesuai dengan farâ'id. Namun berdasarkan tasâluh, hal ini terjadi karena telah menajdi adat istiadat pada masyarakat adat Karampuang yang diwariskan oleh nenek moyangnya secara turun temurun hingga saat ini, demi terciptanya kedamaian masyarakat dan terwujudnya kemaslahatan umat.
\end{abstract}

Kata kunci : Pelaksanaan, Hukum Adat, Harta Warisan, Hukum Islam.

\begin{abstract}
This study aims to determine the practice of the distribution of customary inheritance, and the implementation of Islamic inheritance law in the Karampuang indigenous people, in Bulupoddo District, Sinjai Regency. This type of research is descriptive qualitative (field research) and the research approach used; normative (shar'i), formal juridical approach, sociological approach, normative approach, phenomenological approach. The data sources of this research are traditional leaders, heirs, religious leaders and community leaders, then the data collection methods used are observation, interviews, documentation and reference tracking. Then, data processing and analysis techniques are carried out through three stages, namely; data reduction, data presentation and conclusion drawing.
\end{abstract}




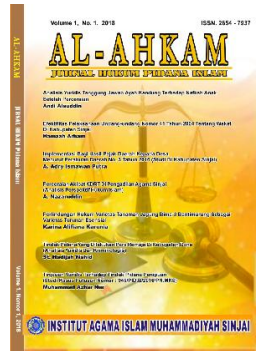

Based on the research that the compiler did, that the inheritance in the Karampuang indigenous people adheres to the descendant system by giving automatically the management of inheritance to the oldest son or the oldest daughter who is given a mandate to the heir in managing the inheritance after the heir's death, only on the estate Certain fields such as rice fields, gardens, money and gold are still held for distribution to other heirs. It aims to provide provisions for the heirs, only part of the inheritance for the oldest son or the oldest daughter more. the system and practice of distributing inheritance to the Karampuang indigenous people is not in accordance with farâ'id. But based on tasâluh, this happens because it has become a custom in the Karampuang indigenous people who have been passed down by their ancestors to this day, for the sake of creating community peace and the realization of the benefit of the people.

Keywords: Implementation, Customary Law, Inheritance, Islamic Law.

\section{Pendahuluan}

Hukum kewarisan selalu menarik untuk dikaji, dalam hubungannya dengankondisi sosio kultural masyarakat Indonesia. Hal ini terjadi karena hukum kewarisan yang berlaku di Indonesia masih bersifat pluralistik, maksudnya masing-masing golongan masyarakat mempunyai hukum sendiri-sendiri. (M. Toha Abdurahham, 1976).

Sebagaimana kita ketahui bersama bahwa kewarisan Islam mengatur peralihan harta dari seseorang yang telah meninggal kepada yang masih hidup. (Amir Syarifuddin, 2004), Setidaknya ada tiga jenis hukum kewarisan yang masih tetap eksis dan hidup di tengah-tengah masyarakat adalah sebagai berikut:

1. Hukum berdasarkan syariat Islam, seperti tertuang dalam ilmu farâ'id. (Ahmad Azhar Basyir,2001)

2. Hukum kewarisan adat yang sangat pluralistis keadaannya dan sifatnya tidak tertulis.

3. Hukum kewarisan berdasarkan Kitab Undang-undang Hukum Perdata (KUHP Perdata)/BW. (M. Toha Abdurahham, 1976).

Dari ketiga jenis hukum kewarisan tersebut yang masih tetap eksis dan hidup di tengah-tengah masyarakat, yang paling dominan dalam pelaksanaan pembagian warisan masyarakat Indonesia adalah berdasarkan hukum Islam dan hukum adat. Hal ini terjadi karena masyarakat Indonesia mayoritas penduduknya beragama Islam dengan berbagai suku yang sangat beragam, yang tentunya pelaksanaan pembagian harta warisan pun akan beragam pula sesuai dengan sistem kekeluargaan yang mereka anut.

Hukum kewarisan menduduki tempat amat penting dalam hukum Islam. Ayat alQur'an mengatur hukum kewarisan dengan jelas dan terperinci. Hal ini dapat dimengerti sebab masalah warisan pasti dialami oleh setiap orang, karena hukum kewarisan langsung menyangkut harta benda yang apabila tidak diberikan ketentuan pasti amat mudah menimbulkan sengketa di antara ahli waris. Setiap terjadi peristiwa kematian seseorang, segera timbul bagaimana harta peninggalannya harus diberlakukan dan kepada siapa saja harta itu dipindahkan, serta bagaimana caranya. Inilah yang diatur dalam hukum waris. (M. Toha Abdurahham, 1976).

Dalam sejarah perjalanan hukum Islam di Indonesia sejak zaman pemerintahan Hindia Belanda sampai sekarang telah melahirkan beberapa titik singgung. Selanjutnya 


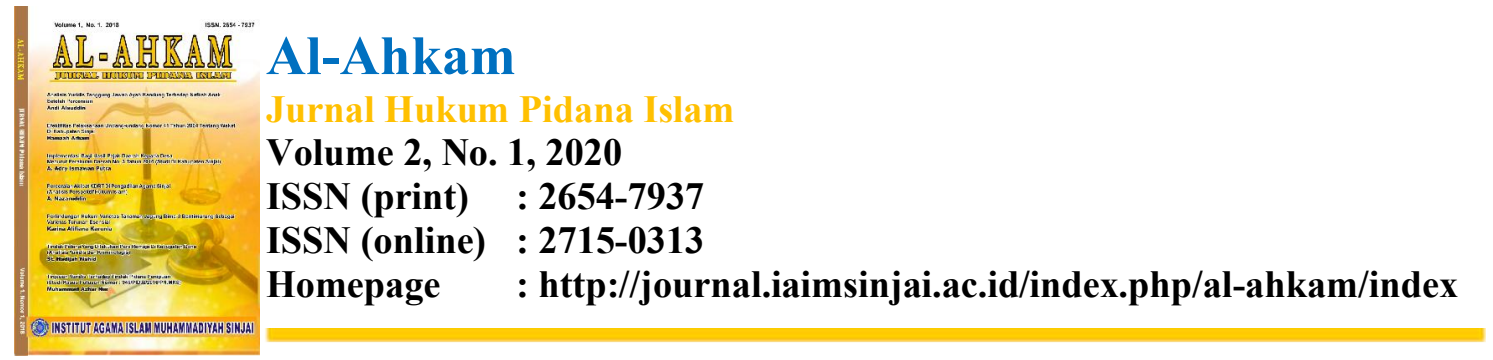

titik singgung tersebut dikedepankan sebagai teori yang berkaitan dengan realita yang dihadapi oleh hukum Islam. Ketika hukum Islam hendak menanamkan nilai-nilainya sebagai landasan kesadaran hukum yang mengatur tata tertib masyarakat, ketika itu pula ia berhadapan dengan nilai-nilai kesadaran hukum adat. (Haeruddin, 2017), Setelah agama Islam berkembang, maka secara berangsur-ansur pula Islam dapat mempengaruhi sistem kepemilikan harta dan warisan ini. (Yaswirman, 2017)

Hukum kewarisan adat di Indonesia sangat dipengaruhi oleh prinsip garis keturunan yang berlaku pada masyarakat yang bersangkutan, yang mungkin merupakan patrilineal murni, patrilineal beralih-alih (alternerend) matrilineal ataupun bilateral (walaupun sukar ditegaskan dimana berlakunya di Indonesia), ada pula prinsip unilateral berganda (dubbel-unilateral). Prinsip-prinsip garis keturunan terutama berpengaruh terhadap penetapan ahli waris maupun bagian harta peninggalan yang diwariskan (baik yang material maupun immaterial). (Soerjono Soekanto, 2002)

Hukum kewarisan adat adalah hukum adat yang memuat garis-garis ketentuan tentang sistem dan azas-azas hukum kewarisan, tentang harta warisan, pewaris dan ahli waris serta cara bagaimana harta warisan itu dialihkan penguasaan dan pemilikannya dari pewaris kepada waris. Hukum kewarisan adat sesungguhnya adalah hukum penerusan harta kekayaan dari suatu generasi kepada keturunannya. (Hilman Hadikusuma, 2003)

Hubungan hukum adat dengan hukum Islam dalam makna kontak antara kedua sistem hukum itu telah lama berlangsung di Indonesia. Hubungannya akrab dalam masyarakat. Keakraban itu tercermin dalam berbagai pepatah dan ungkapan yang berbunyi: Hukum ngon adat hantom cre, lagee zat ngon sipuet. Artinya hukum Islam dengan hukum adat tidak dapat dicerai-pisahkan karena erat sekali hubungannya seperti hubungan zat dengan sifat sesuatu barang atau benda. Seperti halnya di Minangkabau yang tercermin dalam pepatah: Adat dan syara' sanda pepatah, syara' mengato adat memakai. Makna dari pepatah ini adalah hukum adat dengan hukum Islam erat sekali, saling topang-menopang, karena yang sesunngguhnya yang dinamakan adat yang benar-benar adat adalah syara' itu sendiri. (Mohammad Daud Ali, 1991)

\section{Metodologi Penelitian}

\section{Jenis dan Lokasi Penelitian}

a. Jenis Penelitian

Jenis penelitian yang akan digunakan dalam penelitian ini adalah field research deskriftif kualitatif tentang pelaksanaan hukum kewarisan Islam pada masyarakat adat Karampuang di Kecamatan Bulupoddo Kabupaten Sinjai, atau dikategorikan juga sebagai penelitian lapangan (field research), yaitu pencarian yang secara langsung di lapangan atau lokasi penelitian. Kemudian untuk menunjang penelitian ini penulis juga melakukan penelahan terhadap buku-buku yang relevan dengan topik penelitian ini. (S. Nasution, 1996)

b. Lokasi Penelitian

Langkah awal untuk penelitian yaitu menentukan serta menetapkan lokasi penelitian. Menurut S. Nasution bahwa ada tiga unsur yang harus diperhatikan dalam penelitian, antara lain adalah : menetapkan lokasi, tempat, pelaku, dan aktifitas kegiatan. 


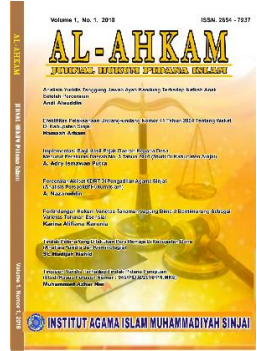

Volume 2, No. 1, 2020

ISSN (print) : 2654-7937

ISSN (online) : 2715-0313

Homepage : http://journal.iaimsinjai.ac.id/index.php/al-ahkam/index

Adapun lokasi pada penelitian ini yaitu bertempat di kawasan adat Karampuang Kecamatan Bulupoddo Kabupaten Sinjai.

\section{Pendekatan Penelitian}

Adapun pendekatan yang digunakan pada penelitian ini adalah sebagai berikut:

a. Pendekatan Normatif (Syar'i), yaitu pendekatan terhadap suatu masalah yang didasarkan pada hukum Islam, baik berasal dari al-Qur'an, hadis, kaidah ushul fiqh dan pendapat para ulama terkait dengan pelaksanaan hukum Islam. (Abuddin Nata, 2004)

b. Pendekatan Yuridis Formal, adalah pendekatan pada asas-asas hukum yang mendasari ketentan peraturan, seperti misalnya perundang-undangan tidak boleh menyimpang dari undang-undang dasar 1945 (UUD 1945).

c. Pendekatan Sosiologis, adalah pendekatan dalam memahami Islam dari kerangka ilmu sosial, atau yang berkaitan dengan aspek hubungan sosial manusia antara yang satu dengan yang lain, atau antara kelompok yang satu dengan yang lain. (Supiana, 2012)

d. Pendekatan Fenomenologis, yaitu suatu pendekatan yang diuapayakan dengan melihat dan memperhatikan keadaan keragaman masyarakat. Adat Karampuang, khususnya pada praktik pelaksanaan Hukum Kewarisan Islam pada Masyarakat Adat Karampuang di Kecamatan Bulupoddo Kabupaten Sinjai.

\section{Sumber Data Penelitian}

sumber data atau informan dalam penelitian ini terdiri dari dua sumber yaitu, data primer dan data sekunder. Sumber data primer dalam penelitian ini adalah berupa wawancara kepada informan, seperti: tokoh adat, tokoh masyarakat, tokoh agama, serta perwakilan dari pihak pemerintah setempat. Data primer merupakan sumber data yang penelitian yang diperoleh secara langsung dari sumber asli (tanpa perantara). Sedangkan data sekunder yang dipakai dalam penelitian ini berupa buku-buku sebagai referensi serta Teori-teori pembelakuan hukum Islam yang berkaitan dengan pelaksanaan hukum kewarisan Islam pada masyarakat adat. Serta pandangan para Ulama yang tertuang dalam kitab-kitab fikih klasik dan kontemporer yang berkaitan dengan penelitian.

\section{Metode Pengumpulan Data}

a. Wawancara

Guna memperoleh data dalam penelitian ini penyusun menggunakan metode sebagai berikut:

1) Observasi, yakni mengamati langsung ke lapangan dalam hubungannya dengan masalah yang akan diteliti untuk dianalisa dan dikumpulkan.

2) Interview (wawancara): yaitu dengan mengajukan pertanyaan secara langsung (lisan) kepada pihak-pihak yang mendukung tercapainya tujuan penelitian ini. Wawancara dilakukan pada informan, tokoh agama, tokoh adat dan tokoh masyarakat setempat.

\section{Pembahasan}

\section{Sistem kewarisan}

Sampai saat ini di Indonesia belum terbentuk hukum kewarisan secara nasional yang dapat mengatur pewarisan secara nasional. Sehingga dalam hukum kewarisan di Indonesia dapat menggunakan berbagai macam sistem pewarisan antara lain: sistem hukum kewarisan menurut KUH Perdata, sistem kewarisan menurut hukum adat dan sistem kewarisan menurut hukum Islam. Ketiga sistem ini semua berlaku dikalangan masyarakat 


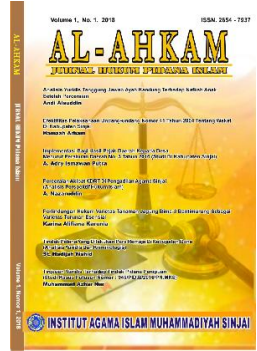

hukum di Indonesia. Terserah para pihak untuk memilih hukum apa yang akan digunakan dalam pembagian harta warisan yang dipandang cocok dan mencerminkan rasa keadilan. (Maryanti Bachtiar)

Sebagai negara yang mayoritas penduduknya beragama Islam dimungkinkan banyak dari anggota masyarakat yang mengunakan sistem hukum Islam. Tetapi seiring dengan perkembangangan zaman yang ditandai dengan kemajuan dan teknologi prinsipprinsip dalam hukum Islam terus mengalami kemajuan yang pesat dan selalu mengikuti perubahan zaman guna untuk kemaslahatan umat di dunia. Tanpa membedakan baik lakilaki maupun perempuan.

Sistem hukum kewarisan Islam adalah sistem kewarisan yang pelaksanaan dan penyelesaian harta warisan itu apabila pewaris wafat. Jika ada yang wafat maka ada masalah waris. Apabila ada seseorang yang meninggalkan harta kekayaan maka berarti ada harta warisan yang harus dibagi-bagikan kepada para ahli waris pria atau wanita yang masih hidup dan juga memberikan bagian kepada anak-anak yatim dan fakir miskin. Dibeberapa daerah di mana ajaran Islam telah mendarah daging sistem kewarisan Islam ini berlaku. Sistem ini menurut Hazairin merupakan sistem individual bilateral. (Hilman Hadikusuma, 2003)

Dasar atau dalil berlakunya sstem individual bilateral adalah QS an-Nisa/4:7-8:

Terjemahnya :

Bagi lki-laki ada hak bagian dari harta peninggalan ibu bapak dan kerabatnya, dan bagi wanita ada hak bagian (pula) dari harta peninggalan ibu bapak dan kerabatnya, baik sedikit atau banyak menurut bagian yang telah ditetapkan. Dan apabila kerabat (yang tidak termasuk ahli waris), anak yatim, dan orang miskin hadir sewaktu pembagian (harta warisan) itu hadir, maka berilah mereka dari harta itu (sekadarnya) dan ucapkanlah kepada mereka perkataan yang baik.

Kemudian terdapat pula dalil naqli dalam QS an-Nisa/4:33:

Terjemahnya :

Bagi tiap-tiap harta peninggalan dari harta yang ditinggalkan kedua orang tua dan karib kerabat, Kami jadikan pewaris-pewarisnya. Dan (jika ada) orang-orang yang kamu telah bersumpah setia dengan mereka, maka berilah kepada mereka bagiannya. Sesungguhnya Allah menyaksikan segala sesuatu.

Sistem kewarisan yang diberlakukan dalam masyarakat adat Karampuang adalah sistem dan praktik penerusan dan pengalihan hak penguasaan atas harta yang akan dibagibagi kepada seluruh ahli waris dilimpahkan kepada anak laki-laki tertua atau anak perempuan tertua yang bertugas sebagai pemimpin rumah tangga atau kepala keluarga menggantikan kedudukan ayah atau ibu sebagai kepala keluarga.

Kelemahan dan kebaikan Sistem pewarisan seperti ini terletak pada kepemimpinan yang menjadi ahli waris utama, dalam kedudukannya sebagai pengganti orang tua yang telah wafat dalam mengurus harta kekayaan dan memanfaatkannya guna kepentingan semua anggota keluarga yang ditinggalkan. Ahli waris utama yang penuh tanggungjawab akan dapat mempertahankan keutuhan dan kerukunan keluarga sampai 


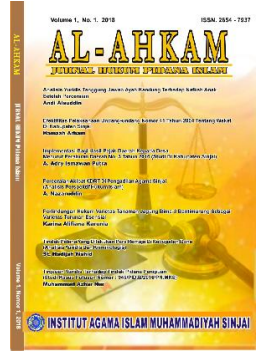

semua ahli waris menjadi dewasa dan dapat berdiri sendiri mengatur rumah tangga sendiri. Tetapi ahli waris uatama yang tidak bertanggungjawab, yang tidak dapat mengendalikan diri terhadap kebendaan atau harta warisan, yang pemboros dan lain sebagainya, jangankan akan dapat mengurus harta peninggalan dan saudara-saudaranya malahan sebaliknya dia yang diurus oleh anggota keluarga yang lain.

Sistem kewarisan seperti ini seringkali disalah tafsirkan, tidak saja oleh orang yang tidak memahaminya, tetapi juga oleh pihak ahli waris utama itu sendiri. Ahli waris yang dipercayakan sebagai pengganti orang tua yang telah meninggal bukanlah pemilik harta peninggalan secara perseorangan, dia hanya berkedudukan sebagai penguasa, sebagai pemegang mandat orang tua yang dibatasi oleh musyawarah keluarga, dibatasi oleh kewajiban mengurus anggota keluarga lain yang ditinggalkan, tidak semata-mata berdasarkan harta peninggalan tetapi juga berdasarkan asas tolong menolong oleh bersama untuk bersama.

Untuk menghindari adanya perselisihan di antara para para ahli waris dikemudian hari, pewaris dimasa hidupnya seringkali telah menunjukkan bagaimana cara mengatur harta kekayaan keluarganya. Jadi sebelum pewaris meninggal dia telah berpesan yang disampaikannya dengan terang kepada isteri/suami yang ditinggalkan dan anakanaknya tentang bagaimana kedudukan harta kekayaannya kelak apabila dia telah wafat.

Walaupun demikian ada ketetapan dan ancaman AllahSWT, mengenai pembagian harta warisan yang harus ditaati oleh umat Islam, dijelaskan dalam QS anNisa/4:14:

Terjemahnya :

Dan barang siapa yang mendurhakai Allah dan rasul-Nya dan melanggar ketentuan-ketentuan-Nya, niscaya Allah memasukkannya ke dalam api neraka sedang ia kekal di dalamnya; dan baginya siksa yang menghinakan.

\section{Praktik Pembagian Harta Warisan}

a. Harta Warisan

Menurut Ahmad Azhar Basyir, dalam bukunya hukum waris Islam, yang dimaksud dengan harta warisan adalah benda berwujud atau hak kebendaan yang ditinggalkan pewaris. Namun, pada di Indonesia), ada pula prinsip unilateral berganda (dubbel-unilateral). Prinsip-prinsip garis keturunan terutama berpengaruh terhadap penetapan ahli waris maupun bagian harta peninggalan yang diwariskan (baik yang material maupun immaterial). (Soerjono Soekanto, 2002)

Hukum kewarisan adat adalah hukum adat yang memuat garis-garis ketentuan tentang sistem dan azas-azas hukum kewarisan, tentang harta warisan, pewaris dan ahli waris serta cara bagaimana harta warisan itu dialihkan penguasaan dan pemilikannya dari pewaris kepada waris. Hukum kewarisan adat sesungguhnya adalah hukum penerusan harta kekayaan dari suatu generasi kepada keturunannya. (Hilman Hadikusuma, 2003)

Hubungan hukum adat dengan hukum Islam dalam makna kontak antara kedua sistem hukum itu telah lama berlangsung di Indonesia. Hubungannya akrab dalam masyarakat. Keakraban itu tercermin dalam berbagai pepatah dan ungkapan yang berbunyi: Hukum ngon adat hantom cre, lagee zat ngon sipuet. Artinya hukum Islam dengan hukum adat tidak dapat dicerai-pisahkan karena erat sekali hubungannya seperti hubungan zat dengan sifat sesuatu barang atau benda. Seperti halnya di Minangkabau yang tercermin dalam pepatah: Adat dan syara' sanda pepatah, syara' mengato adat memakai. Makna dari pepatah ini adalah hukum adat dengan hukum Islam erat sekali, saling topang-menopang, karena yang sesunngguhnya yang dinamakan adat yang benar-benar adat adalah syara' itu sendiri. (Mohammad Daud Ali, 1991) 


\section{Metodologi Penelitian}

\section{Jenis dan Lokasi Penelitian}

c. Jenis Penelitian

Jenis penelitian yang akan digunakan dalam penelitian ini adalah field research deskriftif kualitatif tentang pelaksanaan hukum kewarisan Islam pada masyarakat adat Karampuang di Kecamatan Bulupoddo Kabupaten Sinjai, atau dikategorikan juga sebagai penelitian lapangan (field research), yaitu pencarian yang secara langsung di lapangan atau lokasi penelitian. Kemudian untuk menunjang penelitian ini penulis juga melakukan penelahan terhadap buku-buku yang relevan dengan topik penelitian ini. (S. Nasution, 1996)

\section{d. Lokasi Penelitian}

Langkah awal untuk penelitian yaitu menentukan serta menetapkan lokasi penelitian. Menurut S. Nasution bahwa ada tiga unsur yang harus diperhatikan dalam penelitian, antara lain adalah : menetapkan lokasi, tempat, pelaku, dan aktifitas kegiatan. Adapun lokasi pada penelitian ini yaitu bertempat di kawasan adat Karampuang Kecamatan Bulupoddo Kabupaten Sinjai.

\section{Pendekatan Penelitian}

Adapun pendekatan yang digunakan pada penelitian ini adalah sebagai berikut:

e. Pendekatan Normatif (Syar'i), yaitu pendekatan terhadap suatu masalah yang didasarkan pada hukum Islam, baik berasal dari al-Qur'an, hadis, kaidah ushul fiqh dan pendapat para ulama terkait dengan pelaksanaan hukum Islam. (Abuddin Nata, 2004)

f. Pendekatan Yuridis Formal, adalah pendekatan pada asas-asas hukum yang mendasari ketentan peraturan, seperti misalnya perundang-undangan tidak boleh menyimpang dari undang-undang dasar 1945 (UUD 1945).

g. Pendekatan Sosiologis, adalah pendekatan dalam memahami Islam dari kerangka ilmu sosial, atau yang berkaitan dengan aspek hubungan sosial manusia antara yang satu dengan yang lain, atau antara kelompok yang satu dengan yang lain. (Supiana, 2012)

h. Pendekatan Fenomenologis, yaitu suatu pendekatan yang diuapayakan dengan melihat dan memperhatikan keadaan keragaman masyarakat. Adat Karampuang, khususnya pada praktik pelaksanaan Hukum Kewarisan Islam pada Masyarakat Adat Karampuang di Kecamatan Bulupoddo Kabupaten Sinjai.

\section{Sumber Data Penelitian}

sumber data atau informan dalam penelitian ini terdiri dari dua sumber yaitu, data primer dan data sekunder. Sumber data primer dalam penelitian ini adalah berupa wawancara kepada informan, seperti: tokoh adat, tokoh masyarakat, tokoh agama, serta perwakilan dari pihak pemerintah setempat. Data primer merupakan sumber data yang penelitian yang diperoleh secara langsung dari sumber asli (tanpa perantara). Sedangkan data sekunder yang dipakai dalam penelitian ini berupa buku-buku sebagai referensi serta Teori-teori pembelakuan hukum Islam yang berkaitan dengan pelaksanaan hukum kewarisan Islam pada masyarakat adat. Serta pandangan para Ulama yang tertuang dalam kitab-kitab fikih klasik dan kontemporer yang berkaitan dengan penelitian.

\section{Metode Pengumpulan Data}

b. Wawancara 


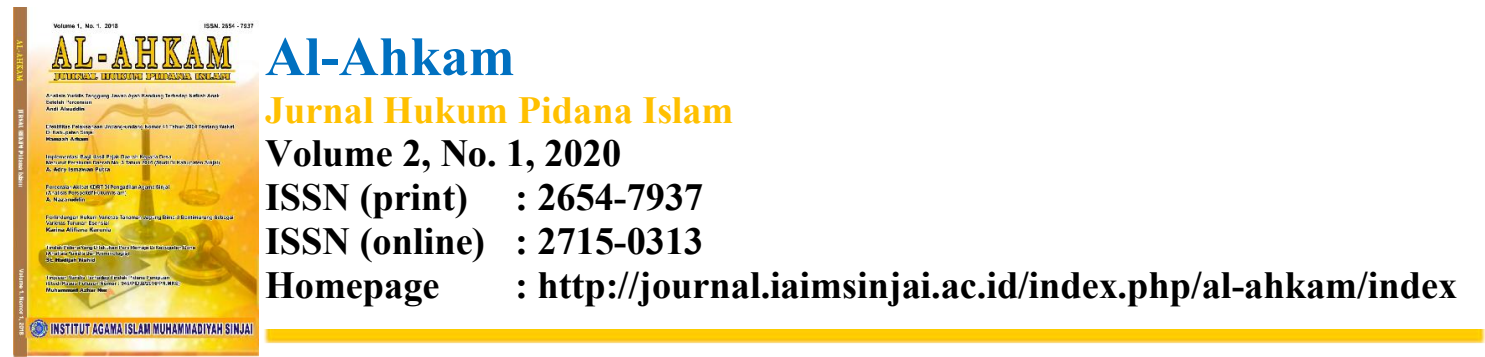

Guna memperoleh data dalam penelitian ini penyusun menggunakan metode sebagai berikut:

3) Observasi, yakni mengamati langsung ke lapangan dalam hubungannya dengan masalah yang akan diteliti untuk dianalisa dan dikumpulkan.

4) Interview (wawancara): yaitu dengan mengajukan pertanyaan secara langsung (lisan) kepada pihak-pihak yang mendukung tercapainya tujuan penelitian ini. Wawancara dilakukan pada informan, tokoh agama, tokoh adat dan tokoh masyarakat setempat.

\section{Pembahasan}

\section{Sistem kewarisan}

Sampai saat ini di Indonesia belum terbentuk hukum kewarisan secara nasional yang dapat mengatur pewarisan secara nasional. Sehingga dalam hukum kewarisan di Indonesia dapat menggunakan berbagai macam sistem pewarisan antara lain: sistem hukum kewarisan menurut KUH Perdata, sistem kewarisan menurut hukum adat dan sistem kewarisan menurut hukum Islam. Ketiga sistem ini semua berlaku dikalangan masyarakat hukum di Indonesia. Terserah para pihak untuk memilih hukum apa yang akan digunakan dalam pembagian harta warisan yang dipandang cocok dan mencerminkan rasa keadilan. (Maryanti Bachtiar)

Sebagai negara yang mayoritas penduduknya beragama Islam dimungkinkan banyak dari anggota masyarakat yang mengunakan sistem hukum Islam. Tetapi seiring dengan perkembangangan zaman yang ditandai dengan kemajuan dan teknologi prinsipprinsip dalam hukum Islam terus mengalami kemajuan yang pesat dan selalu mengikuti perubahan zaman guna untuk kemaslahatan umat di dunia. Tanpa membedakan baik lakilaki maupun perempuan.

Sistem hukum kewarisan Islam adalah sistem kewarisan yang pelaksanaan dan penyelesaian harta warisan itu apabila pewaris wafat. Jika ada yang wafat maka ada masalah waris. Apabila ada seseorang yang meninggalkan harta kekayaan maka berarti ada harta warisan yang harus dibagi-bagikan kepada para ahli waris pria atau wanita yang masih hidup dan juga memberikan bagian kepada anak-anak yatim dan fakir miskin. Dibeberapa daerah di mana ajaran Islam telah mendarah daging sistem kewarisan Islam ini berlaku. Sistem ini menurut Hazairin merupakan sistem individual bilateral. (Hilman Hadikusuma, 2003)

Dasar atau dalil berlakunya sstem individual bilateral adalah QS an-Nisa/4:7-8:

Terjemahnya :

Bagi lki-laki ada hak bagian dari harta peninggalan ibu bapak dan kerabatnya, dan bagi wanita ada hak bagian (pula) dari harta peninggalan ibu bapak dan kerabatnya, baik sedikit atau banyak menurut bagian yang telah ditetapkan. Dan apabila kerabat (yang tidak termasuk ahli waris), anak yatim, dan orang miskin hadir sewaktu pembagian (harta warisan) itu hadir, maka berilah mereka dari harta itu (sekadarnya) dan ucapkanlah kepada mereka perkataan yang baik. 


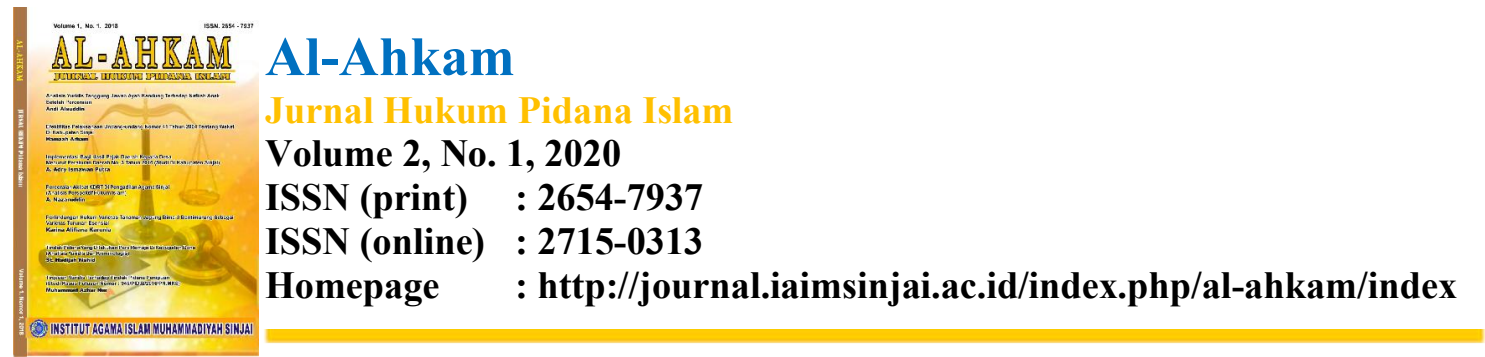

Kemudian terdapat pula dalil naqli dalam QS an-Nisa/4:33:

Terjemahnya :

Bagi tiap-tiap harta peninggalan dari harta yang ditinggalkan kedua orang tua dan karib kerabat, Kami jadikan pewaris-pewarisnya. Dan (jika ada) orang-orang yang kamu telah bersumpah setia dengan mereka, maka berilah kepada mereka bagiannya. Sesungguhnya Allah menyaksikan segala sesuatu.

Sistem kewarisan yang diberlakukan dalam masyarakat adat Karampuang adalah sistem dan praktik penerusan dan pengalihan hak penguasaan atas harta yang akan dibagibagi kepada seluruh ahli waris dilimpahkan kepada anak laki-laki tertua atau anak perempuan tertua yang bertugas sebagai pemimpin rumah tangga atau kepala keluarga menggantikan kedudukan ayah atau ibu sebagai kepala keluarga.

Kelemahan dan kebaikan Sistem pewarisan seperti ini terletak pada kepemimpinan yang menjadi ahli waris utama, dalam kedudukannya sebagai pengganti orang tua yang telah wafat dalam mengurus harta kekayaan dan memanfaatkannya guna kepentingan semua anggota keluarga yang ditinggalkan. Ahli waris utama yang penuh tanggungjawab akan dapat mempertahankan keutuhan dan kerukunan keluarga sampai semua ahli waris menjadi dewasa dan dapat berdiri sendiri mengatur rumah tangga sendiri. Tetapi ahli waris uatama yang tidak bertanggungjawab, yang tidak dapat mengendalikan diri terhadap kebendaan atau harta warisan, yang pemboros dan lain sebagainya, jangankan akan dapat mengurus harta peninggalan dan saudara-saudaranya malahan sebaliknya dia yang diurus oleh anggota keluarga yang lain.

Sistem kewarisan seperti ini seringkali disalah tafsirkan, tidak saja oleh orang yang tidak memahaminya, tetapi juga oleh pihak ahli waris utama itu sendiri. Ahli waris yang dipercayakan sebagai pengganti orang tua yang telah meninggal bukanlah pemilik harta peninggalan secara perseorangan, dia hanya berkedudukan sebagai penguasa, sebagai pemegang mandat orang tua yang dibatasi oleh musyawarah keluarga, dibatasi oleh kewajiban mengurus anggota keluarga lain yang ditinggalkan, tidak semata-mata berdasarkan harta peninggalan tetapi juga berdasarkan asas tolong menolong oleh bersama untuk bersama.

Untuk menghindari adanya perselisihan di antara para para ahli waris dikemudian hari, pewaris dimasa hidupnya seringkali telah menunjukkan bagaimana cara mengatur harta kekayaan keluarganya. Jadi sebelum pewaris meninggal dia telah berpesan yang disampaikannya dengan terang kepada isteri/suami yang ditinggalkan dan anakanaknya tentang bagaimana kedudukan harta kekayaannya kelak apabila dia telah wafat.

Walaupun demikian ada ketetapan dan ancaman AllahSWT, mengenai pembagian harta warisan yang harus ditaati oleh umat Islam, dijelaskan dalam QS anNisa/4:14:

Terjemahnya :

Dan barang siapa yang mendurhakai Allah dan rasul-Nya dan melanggar ketentuan-ketentuan-Nya, niscaya Allah memasukkannya ke dalam api neraka sedang ia kekal di dalamnya; dan baginya siksa yang menghinakan.

\section{Praktik Pembagian Harta Warisan}

b. Harta Warisan

Menurut Ahmad Azhar Basyir, dalam bukunya hukum waris Islam, yang dimaksud dengan harta warisan adalah benda berwujud atau hak kebendaan yang ditinggalkan pewaris. Namun, pada harta peninggalan itu terlekat hak yang harus ditunaikan, yaitu hak si pewaris sendiri yang berupa biaya penyelenggaraan jenazahnya, sejak dimandikan sampai dimakamkan; kemudian hak para kreditur; kemudian orang atau 


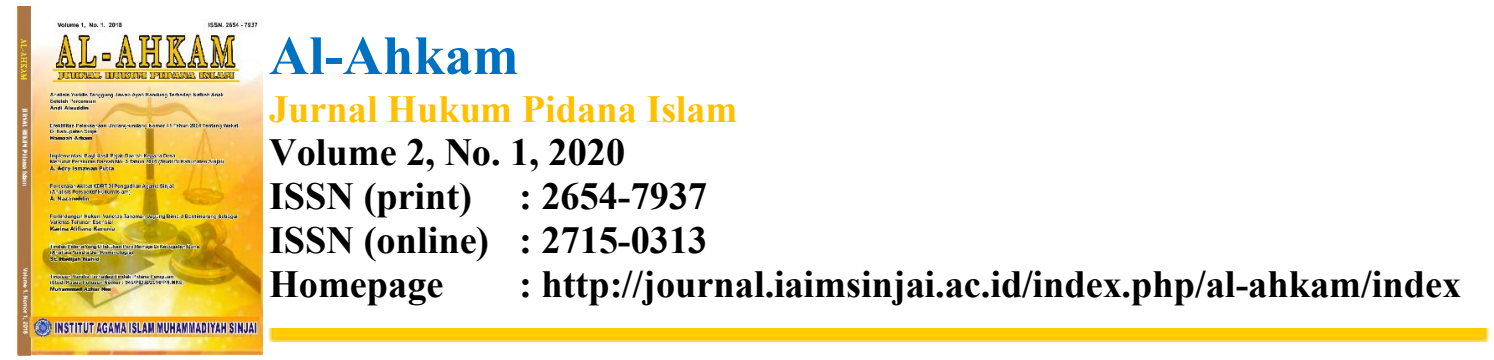

badan yang menerima wasiat pewaris. Setelah tiga macam hal itu ditunaikan, barulah para ahli waris berhak atas harta peninggalan itu. (Ahmad Azhar Basyir, 2001)

Sementara dalam pandangan masyarakat adat Karampuang salah satu tokoh masyarakat Muh. Ihsan mengatakan bahwa harta warisan adalah segala harta benda yang ditinggalkan karena matinya seseorang akan beralih kepada orang lain yang dalam hal ini disebut sebagai ahli warisnya setelah harta itu disisihkan segala yang menyangkut dengan si mayit seperti segala biaya pemakamannya (pelaksanaan fardu kifayahnya), hutang piutang dan sebagainya.

Menurut Mangga Puang Gella, Adat Karampuang mengatakan dalam masyarakat adat Karampuang pembagian harta warisan dapat dibedakan menjadi dua bagian yaitu, harta peninggalan terbagi secara khusus dan harta peninggalan terbagi kepada seluruh ahli waris, yang pertama: harta peninggalan terbagi secara khusus, yaitu jika ada harta warisan yang akan dibagikan kepada ahli waris selain daripada rumah, maka rumah beserta isinya atau parabotnya akan secara otomatis akan menjadi kewenangan ahli waris utama yang kepemilikannya diberikan kepada anak kandung yang paling mudah atau bungsu baik lakilaki maupun perempuan, namun rumah tersebut nantinya berfungsi sebagai harta kerabat yang tempat kembalinya semua ahli waris, maka konsekuensinya apabila rumah itu dijual harus sepengetahuan keluarga/ahli waris utama yang telah diberi mandat oleh pewaris dan hasil dari penjualan nantinya dilakukan pembagian kepada ahli waris yang lain jika harta warisan berupa rumah saja, berbeda halnya jika ada harta warisan yang dibagikan kepada ahli waris yang lain, maka hasil jual rumah menjadi mutlak hak anak kandung paling mudah atau bungsu. Kedua: harta peninggalan terbagi kepada seluruh ahli waris. Harta peninggalan terbagi kepada seluruh ahli waris adalah harta yang berbentuk tanah, uang, emas, aset dan sebagainya selain daripada rumah, hal ini bertujuan untuk memberikan bekal kehidupan bagi adik-adiknya dalam berusaha sendiri atau untuk membentuk rumah tangga baru, namun penguasaan dan pembagian terhadap harta peninggalan terbagi ini, masih di bawah kendali anak laki-laki tertua atau anak perempuan yang diberi kepercayaan dalam mengolah harta warisan.

Kebiasaan yang terjadi didalam masyarakat adat Karampuang sebelum harta peninggalan itu siap untuk dibagi-bagi kepada ahli waris, haruslah terlebih dahulu disisihkan atau diselesaikan segala yang berhubungan dengan si mayit, berupa hak dan kewajibannya dari harta peninggalan itu. (Muh. Asri, Tokoh Agama Desa Tompobulu)

c. Ketentuan Golongan Ahli Waris

Hukum kewarisan Islam mengenal tiga golongan ahli waris:

1) Ahli waris yang memperoleh bagian tertentu menurut al-Qur'an dan sunnah Rasul, atau disebut juga ahli waris zâwi al-furud.

2) Ahli warus yang bagiannya tidak ditentukan dalam al-Qur'an maupun Sunnah Rasul, atau disebut juga ahli waris asâbah.

3) Ahli waris yang tidak mempunyai hubungan keluarga dengan pewaris, tetapi tidak termasuk dua golongan waris zâwi al-furud dan asâbah, disebut ahli waris zâwi al-arhâm. (Ahmad Azhar Basyir, 2001)

Menurut hukum kewarisan pada masyarakat adat Karampuang bahwa yang disebut dengan ahli waris adalah pihak-pihak yang mempunyai hubungan darah dengan pewaris, dan tidak terhalang oleh hukum adat untuk mewarisi.

Adapun yang menjadi ahli waris pada masyarakat adat Karampuang yang telah ditentukan oleh adat adalah sebagai berikut:

1. Anak kandung

Anak kandung yang dimaksud yaitu semua anak yang dilahirkan oleh ayah dan ibunya dalam perkawinan yang sah, baik dia laki-laki maupun perempuan. Dalam 


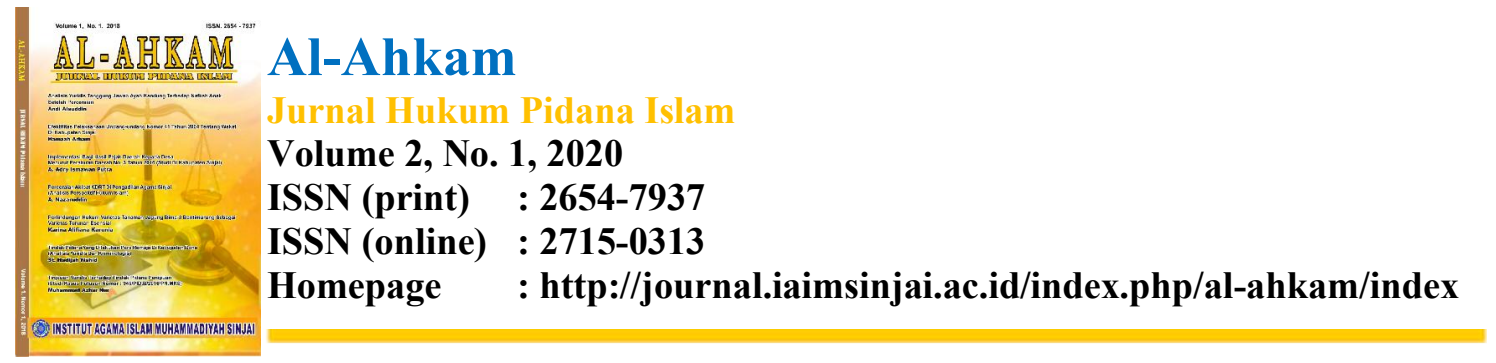

kewarisan pada masyarakat adat Karampuang pihak perempuan sudah termasuk ahli waris yang berhak mendapatkan harta peninggalan orang tuanya. Dalam hal pembagian warisan dari harta peninggalan pewaris utamalah yang telah diberi mandat yang berhak menerimanya, hanya saja kedudukan ahli waris utama bukanlah mutlak menjadi miliknya secara keseluruhan harta warisan tersebut, tetapi ia mempunyai kewajiban untuk membagi harta peninggalan tersebut kepada ahli waris lain.

Menuru Hardi salah satu tokoh masyarakat mengatakan biasanya pembagian dilakukan dalam sebuah musyawarah keluarga dipimpin oleh ahli waris yang telah diberi mandat oleh pewaris sebagai pengganti orang tuanya jika orang tua tersebut sudah tidak ada yang disaksikan oleh para pemangku adat atau para keluarga terdekat yang mempunyai pengaruh terhadap keluarga. Dalam musyawarah bagian masing-masing ditentukan sesuai dengan ketentuan adat yang telah berlaku.

2. Istri atau suami yang ditinggalkan

Isteri atau suami yang ditinggalkan adalah ahli waris yang berhak mendapatkan harta warisan. Namun dalam masyarakat adat Karampuang biasanya jika salah satu dari orang tua masih hidup baik itu ayah maupun ibu, maka harta warisan belum belum dibagikan secara keseluruhan kepada ahli waris, hanya sebatas diatas namakan. Hal ini untuk mencegah nantinya jika dikemudian hari para ahli waris akan menelanrtarkan orang tuanya dan hanya akan tinggal sendiri.

Berdasarkan hasil wawancara terhadap berbagai informan, maka peneliti dapat menarik kesimpulan bahwa hukum kewarisan pada masyarakat adat Karampuang, menjadikan anak laki-laki tertua atau anak perempuan tertua sebagai ahli waris utama dalam keluarga, bukanlah semata-mata karena dia adalah ahli waris utama yang harus selalu dihormati, dan didahulukan segala macam kebutuhannya. Sebenarnya ada beban berat yang harus dipikul di pundaknya. Sebagaimana peneliti kemukakan bahwa anak lakilaki maupun anak perempuan yang diberi mandat mempunyai hak mutlak yang terbatas. Terbatasi oleh musyawarah keluarga dan pengawasan tokoh adat, terbatasi kewajiban mengurus anggota keluarga yang ditinggalkan oleh orang tuanya, tidak semata-mata berdasarkan harta warisan, tetapi juga berdasarkan asas tolong-menolong untuk kemanusiaan, dan juga yang terpenting adalah kewajiban mengurus orang tuanya apabila orang tuanya sudah tua dan tidak mampu lagi untuk mengurus anak-anak yang lain, bahkan kewajiban mengurus orang tua bukan saja ketika mereka masih hidup melainkan sampai mereka meninggal. Kiranya dari sinilah kita dapat menarik benang merah mengapa rumah merupakan benda yang pantang dibagikan kepada ahli waris lain apalagi dijual. Masyarakat adat Karampuang sangat memperhatikan orang tua. Hal tersebut sesuai firman Allah swt. dalam QS al-Isra/17:23:

\section{Terjemahnya :}

Dan Tuhanmu telah memerintahkan supaya kamu jangan menyembah selain Dia dan hendaklah kamu berbuat baik pada kedua orang tua dengan sebaik-baiknya. Jika salah seorang di antara keduanya atau kedua-duanya sampai berumur lanjut dalam pemeliharaanmu, maka sekali-kali janganlah kamu mengatakan kepada keduanya perkataan "ah" dan janganlah kamu membentak mereka, dan ucapkanlah kepada mereka perkataan yang mulia.

Menurut Kepala Desa Tompobulu Mahmudin yang juga merupakan calon ahli waris bahwa dalam pembagian harta warisan tetap diberikan bagian kepada orang tua berupa harta produktif yang dikenal pada masyarakat adat Karampuang yaitu harta warisan yang diberikan kepada orang tua untuk kelangsungan hidupnya, dan untuk biaya 


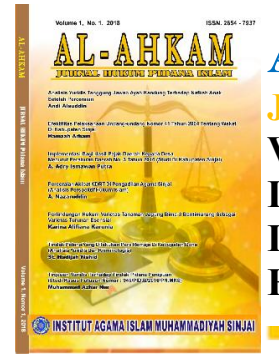

Al-Ahkam

Jurnal Hukum Pidana Islam

Volume 2, No. 1, 2020

ISSN (print) : 2654-7937

ISSN (online) : 2715-0313

Homepage : http://journal.iaimsinjai.ac.id/index.php/al-ahkam/index

pengurusan jenazah ketika nanti orang tuanya meninggal, maka yang berhak mendapatka warisan lebih adalah anak yang merawatnya selama orang tua tersebut masih hidup.

Kedudukan perempuan sudah mendapat tempat sebagaimana mestinya, dimana hal ini dapat kita lihat apabila dalam sebuah keluarga anak kandungnya perempuan semua tidak langsung mengangkat anak angkat sebagai pengganti laki-laki tetapi cukup mendudukkan anak perempuan tertua menggantikan peran anak laki-laki yang tidak ada tersebut, dan juga apabila di antara anak kandung terdapat perempuan maka dia tetap sebagai ahli waris yang berhak mendapat bagian juga. Sebagaimana telah dijelaskan tersebut mengenai para ahli waris serta bagiannya yang terdapat dalam sistem dan praktik kewarisan pada masyarakat adat Karampuang tidak sesuai dengan hukum kewarisan Islam yang telah ditetapkan dalam al-Qur'an karena dalam masyarakat adat Karampuang juga biasanya membagi rata harta warisan dengan memberikan bagian yang sama antara lakilaki dan perempuan.

Menurut Agustina, S.Pd.I tidak dipakainya hukum kewarisan Islam dalam pembagian harta warisan karena masyarakat adat Karampuang menganggap hukum kewarisan adat sudah menyamai hukum kewarisan Islam dan dianggap lebih mudah untuk diterapkan.

Mappiare, SE. selaku mantan kepala Desa Tompobulu juga menilai bahwa tidak dipakainya hukum kewarisan Islam, karena hukum kewarisan adat lebih dahulu muncul keberadaannya dari agama Islam, serta penggunaannya terasa berbelit-belit dan sulit menyebabkan hukum waris Islam berkembang secara signifikan.

Kemudian Muh. Asri mengatakan tidak dipakainya hukum kewarisan Islam karena tidak adanya kewajiban bagi manusia untuk melaksanakannya, penggunaan hukum waris Islam dianggap sebagai alternatif terakhir untuk menyelesaikan perkara warisan. Masyarakat disini lebih mementingkan masalah ibadah saja, persoalan muamalat kurang mendapatkan perhatian dalam pelaksanaannya, sebab yang terpenting bagi masyarakat bagaimana caranya pembagian harta warisan berjalan damai tanpa konflik, sehingga yang diutamakan adalah rasa persatuan keluarga, rasa saling rela dan rasa saling menerima. Hal ini dilakukan untuk menjaga keutuhan dan kerukunan keluarga.

Pelaksanaan hukum kewarisan yang diberlakukan dalam masyarakat adat Karampuang, menjadi hal menarik untuk dikaji, dalam hal pembagian harta warisan yang tidak menggunakan hukum kewarisan Islam terkesan mendua. Disatu sisi merupakan muslim taat beragama, tetapi di sisi lain tidak menjalankan syari'at secara utuh, barangkali hal ini karena kurang kuatnya peranan umat Islam dalam mensosialisasikan hukum Islam sehingga mereka lebih tahu masalah kewarisan adat yang sudah turun-temurun dan mendarah daging. Walaupun demikian, kita tidak bisa mengatakan secara langsung bahwa apa yang dilaksanakan oleh masyarakat adat Karampuang adalah haram, karena bila kita pahami lebih lanjut terhadap praktik pembagian harta warisan pada masyarakat adat Karampuang dengan cara musyawarah dan perdamaian tidaklah merugikan pihak lain. Sebab ahli waris menggunakan hak mereka sesuai dengan kehendak dan atas saling rela para ahli waris dan didalam pembagiannya, yaitu: tentang jumlah dan besarnya bagian masing-masing ditentukan atas dasar ketentuan adat yang disepakati secara bersama-sama. Para ahli waris jika atas kehendaknya sendiri secara sepakat bulat ingin membagi harta warisan mereka secara berdamai atau musyawarah adalah tidak bertentangan dengan syari'at Islam.

Berdasarkan uraian tersebut, maka dapat dikatakan bahwa penyelesaian pembagian harta warisan pada masyarakat adat Karampuang memiliki ketentuan tersendiri, yakni dengan memberikan mandat kepada anak laki-laki tertua atau anak perempuan tertua dalam mengatur harta warisan yang ditingalkan tanpa ada pertikaian. dan 


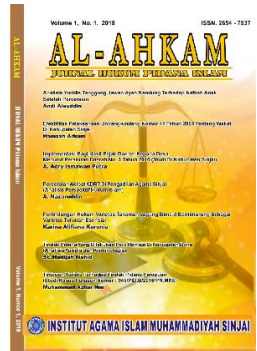

ahli waris yang lainnya mendapatkan bagian atau porsi yang sama. Tentunya perihal tersebut bertentatangan dengan teks ayat kewarisan di dalam al-Qur'an. Akan tetapi masyarakat adat Karampuang juga mengenal rasa saling rela dan saling menerima dari para ahli waris, yang pada hakekatnya tidak bertentangan dengan hukum Islam kategori fiqhi karena sesuai dengan tujuan ditetapkannya syariat Islam yakni menjaga agama, menjaga jiwa, menjaga akal, menjaga keturunan dan menjaga harta, Sehingga dalam hukum Islam kategori fiqhi bahwa pembagian harta warisan pada masyarakat adat Karampuang tidak bertentangan syariat Islam.

Maka hal demikian di bolehkan sepanjang menimbulkan kemudhoratan, demikian pula dalam Kompilasi Hukum Islam (KHI), jika ahli waris bersapakat dengan damai dalam pembagian harta warisan setelah para ahli waris menyadari masing-masing bagiannya, dan perihal tersebut terlepas dari memakan harta dengan jalan yang tidak hak sebagaimana yang dilarang dalam al-Qur'an. Sehingga apabila ada ahli waris pada masyarakat adat Karampuang keberatan yang menimbulkan konflik atau permasalahan dengan sistem dan praktik kewarisan yang digunakan adat tersebut, maka sangat bertentangan dengan hukum Islam maupun Kompilasi Hukum Islam (KHI) karena harus dengan asas kesadaran, kerelaan, kedamaian dan kemaslahatan keluarga, bahkan dapat juga menimbulkan distorsi atau gangguan terhadap agama, jiwa, akal, keturunan dan harta (maqashid syari"ah) yang justru menuai kemudhoratan dalam keluarga dan lingkungan masyarakat.

\section{Penutup}

\section{Kesimpulan}

Berdasarkan pada uraian penelitian yang telah peneliti lakukan, maka dapat kami ambil kesimpulan dari penelitian ini adalah sebagai berikut:

a. Praktik pembagian harta kewarisan pada masyarakat adat Karampuang dikenal dengan adanya pembagian harta warisan kepada seluruh ahli waris. Namun bagian harta warisan untuk anak laki-laki tertua atau perempuan tertua yang diberikan mandat kepada pewaris dalam mengatur harta warisan ketika orang tuanya wafat lebih banyak dibandingkan ahli waris lainnya.

b. Berdasarkan tinjauan hukum Islam, maka sistem dan praktik pembagian harta warisan pada masyarakat adat Karampuang tidak sesuai dengan hukum kewarisan Islam. Namun berdasarkan tasâluh, hal ini terjadi karena telah menajdi adat istiadat pada masyarakat adat Karampuang yang diwariskan oleh nenek moyangnya secara turun temurun hingga saat ini, demi terciptanya kedamaian masyarakat dan terwujudnya kemaslahatan umat.

\section{Implikasi penelitian}

Berdasarkan hasil pemaparan dari penelitian ini, dan ditemukan permasalahan, maka peneliti akan memberikan beberapa implikasi penelitian sebagai berikut:

a. Mengingat hukum kewarisan Islam sangat penting sekali untuk dikembangkan, maka kepada umat Islam umumnya disarankan untuk dapat mempelajari dan sekaligus mengamalkannya sesuai dengan ketentuan syari'at Islam atau menggunakan sistem farâ'id Islah.

b. Kepada para tokoh adat, tokoh agama, tokoh masyarakat dan komponen lainnya, hendaknya mampu memberikan penyuluhan tentang hukum kewarisan Islam, sehingga ada singkronisasi yang lebih signifikan antara sistem dan praktik kewarisan dalam hukum Islam dan sitem kewarisan dalam hukum adat. 


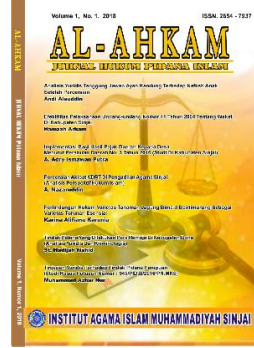

\section{Daftar Pustaka}

\section{Al-Qur'an}

Abdurrahman, M. Toha, Hukum Waris Islam, Cet. XIV; Yogyakarta: UII Pres Yogyakarta, 2001.

Abdurrahman, M. Toha, Pembahasan Waris dan Wasiat Menurut Hukum Islam Yogyakarta: t.p, 1976.

Ali, Mohammad Daud, Hukum Islam: Pengantar Ilmu hukum dan tata Hukum Islam di Indonesia, Cet. II; Jakarta: Raja Grafindo Persada,1991.

Basyir, Ahmad Azhar, Hukum Waris Islam, Yogyakarta: UII Pres, 2001.

Connolly, Peter, (ed,), Aneka Pendekatan Studi Agama, Cet. IV; Yogyakarta: PT. LkiS Yogyakarta, 2012.

Haeruddin, Tinjauan Hukum Islam terhadap sistem kewarisan Adat Desa Ampekale , Kecamatan Bontoa, Kabupaten Maros, Tesis : UIN Alauddin Makassar, 2017.

Hilman Hadikusuma, Hukum Waris Adat, Bandung: PT Citra Aditya Bakti, 2003

Kementerian Agama RI, Al-Qur"an dan terjemahnya, Jakarta: CV. Daarus Sunnah, 2010.

Nasution, S., Metode Naturalistik Kualitatif, Cet. I; Bandung: Tarsito, 1996.

Nata, Abuddin, Metodologi Studi Islam, Cet. IX; Jakarta: PT. Raja Grafindo Persada, 2004.

Narbuko, Cholid, dan Acmadi, Abu, Metodologi Penelitian, Cet. XIII; Jakarta: Bumi Aksara, 2013.

Maryanti Bachtiar, Hukum Waris Dipandang Dari Persfektif Hukum Berkeadilan Gender (Jurnal Hukum Islam).

Supiama, Metodologi Studi Islam Cet. II; Jakarta: Direktorat Jenderal Pendidikan Agama Islam, 2012.

Syarifuddin, Amir, Ushul Fiqh, Jakarta: PT LOGOS Wacana Ilmu, 1999.

Syarifuddin, Amir, Hukum Kewarisan Islam, Cet. I; Jakarta: Prenada Media, 2004.

Syarifuddin, Amir, Garis-garis Besar Fiqh, Cet. I; Bogor: Kencana, 2003.

Yaswirman, Hukum Keluarga Karakteristik dan Prospek Doktrim Islam Dan Adat Dalam Masyarakat Matrilineal Minagkabau, Cet. II; Jakarta: Raja Grafindo Perasada, 2013. 